\title{
sciendo
}

\section{Some considerations of Romanian legal framework on online sale of OTC medicine. Coordination or contradiction to European legislation?}

\author{
Simona GUȚIU \\ Bucharest University of Economic Studies, Bucharest, Romania \\ simona.gutiu@schoenherr.eu
}

\begin{abstract}
The present work is aimed to answer a very interesting and sensitive legal issue in the Romanian pharmaceutical field. This issues regard mainly the existence of coordination or contradiction between Romanian (i.e. Romanian Pharmacy Law no. 266/2008') and European legislation (art 34 TFEU $^{2}$ ) in respect of the delivery of the online sale of OTC medicine only from pharmaceutical units.
\end{abstract}

Keywords: pharmaceutical unit, OTC, European legislation, online sale.

\section{Introduction}

This paper analysis the legal matter of online sale of over the counter medicine (OTC) ${ }^{3}$ through pharmaceutical units located in Romania. According to art. 2 of the Pharmacy Law, the community pharmacy assures the pharmaceutical assistance through the sale and dispensing of OTC on en detail price, without a medical prescription. This paper will also compare the Romanian legislation with the European ones.

The questions which shall be answered within this paper are mainly the following:

a. Whether the Romanian Pharmacy Law imposes a requirement imposed regarding the delivery of OTC medicines sold online only from pharmaceutical units?

b. Such requirement is compliant of not to the European legislation (i.e. Article 34 of the TFEU)?

\section{Legal framework. Relevant provisions in the Romanian law}

In recent years, the Romanian legal framework regarding pharmacies has undergone substantial changes, with a view to implementing the online sale and dispensing of non-prescription medicinal products/OTC medicines. One of the major changes was in respect to the pharmacies' possibility to sell and dispense OTC medicines online, pursuant to the amendment of Pharmacy Law no. 266/2008 ("Pharmacy Law") and the adoption of Order no. 444/2019 for the approval of the Norms on the Establishment, Organization and Operation of Pharmaceutical Units ${ }^{4}$ ("Norms"). Up to that moment, there was no framework for the actual online sale of OTC medicines, in the sense that the customer was only able to reserve such medicines on the pharmacy's website and pick them up from the pharmacy afterwards.

\footnotetext{
${ }^{1}$ Pharmacy Law no. 266/2008 published within the Official Gazette I, no 85/ 02.02.20215, republished, further amended.

${ }^{2}$ Treaty on the Functioning of the European Union (Consolidated version dated 26.10.2012), published within Official Journal of European Union, C 326/47; available on http://data.europa.eu/eli/treaty/tfeu_2012/oj.

${ }^{3}$ Over-the-counter medicine is generally known as OTC or medicine that do not require doctor prescription when buying them from the pharmacy.

${ }^{4}$ Published within the Official Gazette, Part I, no. 270 / 09 April 2019.
} 


\section{Analysis}

The Pharmacy Law imposes a series of requirements to be fulfilled prior to performing the activity of online sale of OTC medicines. Thus, according to Article $2^{1}$ paragraphs (1) and (2) of the Pharmacy Law, in order to sell OTC medicines online, the community pharmacies/ drug stores must be authorized in accordance with the Pharmacy Law and notify the Ministry of Health as regards their intention to perform such activity. The above-mentioned notice shall contain, among other information, the address of the pharmaceutical unit from where the medicines are delivered to the consumer. Thus, it appears that OTC medicines sold online may be delivered to the consumer only from a pharmaceutical unit, within the meaning of the law. Although neither the Pharmacy Law nor the Norms provides for an explicit definition of the "pharmaceutical unit", based on the contents of the appendices to the Norms, a pharmaceutical unit may be organized as (i) community pharmacy; (ii) drugstore; (iii) local distribution officine or (iii) closed circuit pharmacy.

\section{Potential conflict between the Romanian legal provisions and Article 34 of TFEU}

The above-indicated requirement may be deemed as a measure under Article 34 of TFEU. According to Article 34 of TFEU (ex. Article 28 TEC), "Quantitative restrictions on imports and all measures having equivalent effect shall be prohibited between Member States. ${ }^{15}$, while Article 36 of TFEU (ex. Article 30 TEC) stipulates that "The provisions of Articles 34 and 35 shall not preclude prohibitions or restrictions on imports, exports of goods in transit justified on grounds of public morality, public policy or public security; the protection of health and life of humans, animals or plants; the protection of national treasures possessing artistic, historic or archaeological value; or the protection of industrial and commercial property. Such prohibitions or restrictions shall not, however, constitute a means of arbitrary discrimination or a disguised restriction on trade between Member States" 6 .

Furthermore, the decision rendered by the Court of Justice of the European Union ("CJEU") under C-322/017 ("Decision") provides, in brief, that a national prohibition on the sale by mail order of medicinal products the sale of which is restricted to pharmacies is a measure which falls under the quantitative restriction provided under Article 34 of TFEU. Moreover, the Decision stipulates that Article 36 of TFEU may be relied on to justify a national prohibition on the sale by mail order of medicinal products which may be sold only in pharmacies in the Member State concerned in so far as the prohibition covers medicinal products subject to prescription. However, Article 36 of TFEU cannot be relied on to justify an absolute prohibition on the sale by mail order of medicinal products which are not subject to prescription in the Member State concerned (e.g. OTC medicines).

The condition provided under Article $2^{1}$ paragraph (2) of the Pharmacy Law which requires the notifying pharmaceutical unit "the address of the pharmaceutical unit from where the medicines are delivered to the consumer" translates, in practice, into the hindrance of the online selling of medicines by the big pharmacy companies pharmacies directly from their warehouses. Thus, in order to observe the above-mentioned condition, such companies are required to deliver OTC medicines to the consumers from their pharmaceutical units (in most cases, community pharmacies or drugstores), and not directly from their warehouses and/or other such places where the respective

\footnotetext{
${ }^{5}$ https://eur-lex.europa.eu/legal-content/EN/TXT/PDF/?uri=OJ:C:2016:202:FULL\&from=EN.

${ }^{6} \mathrm{https}$ ://eur-lex.europa.eu/legal-content/EN/TXT/PDF/?uri=OJ:C:2016:202:FULL\&from=EN.

${ }^{7}$ Deutscher Apothekerverband eV v DocMorris NV and Jacques Waterval.
} 
medicines are stored. This requirement determines additional costs for pharmacy companies and an inefficient activity.

Notwithstanding the above, Article 85c paragraph 1 of the Directive 2001/83/EC of the European Parliament and of the Council on the Community code relating to medicinal products for human use ${ }^{8}$ ("Directive 83") provides that, without prejudice to national legislation prohibiting the offer for sale at a distance of prescription medicinal products to the public by means of information society services, Member States shall ensure that medicinal products are offered for sale at a distance to the public by means of information society services as defined in Directive (EU) $2015 / 1535^{9}$ ("Directive 1535") and under the conditions provided by Article 85c paragraph 1 of the Directive 83.

As per Article 85c paragraph 1 above, the natural or legal person offering the medicinal products must fulfil the following conditions, among others: (i) has to be authorized or entitled to supply medicinal products to the public, also at a distance, with observance of the corresponding national legal framework of the EU country where that person is established; and (ii) has notified the Member State in which that person is established the information provided by Article $85 \mathrm{c}$ of Directive 83, such as the name or corporate name and permanent address of the place of activity from where those medicinal products are supplied, among others.

By reference to the provisions of the above-mentioned Article 85c paragraph 1 of Directive 83 and Article $2^{1}$ paragraphs (1) and (2) of the Pharmacy Law, it appears that the Romanian legislator included an additional prerequisite for the online sale of medicines (or "sale at a distance to the public", as mentioned under Directive 83), namely the notice regarding the pharmacy's (or the drugstore's) intention to sell and dispense medicines online to be submitted with the competent authority (i.e. Ministry of Healthy) prior to performing such activity shall contain, among other information, the address of the pharmaceutical unit from where the medicinal products are delivered to the consumer (as opposed to the place of activity from where the medicinal products are supplied, mentioned by Directive 83). Therefore, when transposing the provisions of Directive 83 into the Pharmacy Law, the notion "place of activity" was replaced with "pharmaceutical unit" from where the medicinal products are supplied to the public.

Nevertheless, according to Article 85c paragraph 2 of Directive 83, the Member States are allowed to impose conditions, justified on grounds of public health protection, for the retail supply on their territory of medicinal products for sale at a distance to the public by means of information society services.

The TERM of "information society service" means according to Directive 1535 a service generally rendered for a consideration. Such service is either rendered at a distance, by electronic means doubled by the person's request. Analysing this term, one may identify the key elements of the aforementioned definition: (i) a service rendered at a distance means that the service implies that the parties should not be on the same moment present; (ii) a service rendered electronically implies that a person renders a service at a certain moment in time and such service will be received by its recipient through electromagnetic means; and (iii) always upon one's request.

The provisions of Article 85c paragraph 2 of Directive 83 are in line with those of Article 36 of TFEU, which explicitly stipulates that Member States may apply prohibitive measures upon

\footnotetext{
${ }^{8}$ Published within Official Journal of European Union no. 311/28.11.2001; available on https://eur-lex.europa.eu/ legal-content/en/ALL/?uri=CELEX\%3A32001L0083.

${ }^{9}$ Directive 1535 repealed Directive 98/34/EC of the European Parliament and of the Council of 22 June 1998 laying down a procedure for the provision of information in the field of technical standards and regulations.
}

DOI: 10.2478/picbe-2021-0086, pp. 930-935, ISSN 2558-9652|

Proceedings of the $15^{\text {th }}$ International Conference on Business Excellence 2021 
carrying imports, exports of goods in transit only if they have a justified reason (i.e. public protection of health, moral grounds, public policy). By corroborating of the above-mentioned EU legal provisions, it may lead to the interpretation that national rules or practices likely to have a restrictive effect, or having such an effect, on the import of pharmaceutical products are compatible with the TFEU in case in which the public health and life of people is protected.

However, according to the judgment of the Decision, Article 36 of TFEU cannot be relied on to justify an absolute prohibition on the sale by mail order of medicinal products which are not subject to prescription in the Member State concerned (e.g. OTC medicines).

Under such circumstances, the question is whether the Romanian legislator was allowed, by reference to the EU legislation, to impose through the national law harsher requirements for the economic operators who intend to carry out online sale and dispensing of medicines activities on the territory of Romania.

\section{Reason for imposing harsher authorization requirements under the Romanian law for online pharmacies}

In my view, the answer to the question above resides in the explanatory memorandum on amending the Pharmacy Law and Law no. 160/2018 ("Law 160") for amending and supplementing the Pharmacy Law, based on which Article $2^{1}$ was introduced in the Pharmacy Law. As per such memorandum, the Romanian legislator invoked, among others, the following relevant reasons in justify the necessity to sell OTCs online only through pharmacies/ drug stores established under the Pharmacy Law:

a.) the risks to which people who opt for medicines bought online are exposed are extremely high;

b.) the Pharmacy Law (in its version prior to the amendment by Law 160) was imposing a number of extremely restrictive conditions on how pharmacies operate and how medicines are sold, but failed to expressly prohibit online sale thereof by those who have no experience in the field. This determined an exponential growth in the number of websites that sold medicines online, without observing the legal requirements, while the authorities did not have the necessary means to take the necessary measures in order to close such websites;

c.) the Pharmacy Law provides that the use of self-service techniques for human or veterinary drugs is prohibited, as well as the fact that drugs can be sold only in certain locations, which must meet certain criteria and only by people with a certain professional degree, respectively pharmacists;

d.) in the case of certain online stores, the above-mentioned provisions of the Pharmacy Law (in its version prior to the amendment by Law 160) were not observed, except for specialized websites administered by pharmacies established in accordance with the provisions of the Pharmacy Law;

e.) thus, the storage/warehouse space of such online stores did not comply with the instructions of the manufacturer, the specific storage and hygiene requirements during transport were not observed; in addition, it could not be verified whether the persons selling such medicines had any training in this field or not;

f.) medicines that are sold online without observing the relevant legal provisions are not safe for the consumer and, according to studies by the World Health Organization, it is estimated that more than $50 \%$ of drugs sold on the internet are counterfeit; 
g.) many Romanians have made a common practice of self-medication and the only people authorized to recommend drugs are doctors and pharmacists, and purchasing them online, without prior consultation, is not the right solution;

h.) another advantage of the amendments proposed through Law 160 referred to stopping a large phenomenon that can bring serious damage to the health of Romanians and the medical system in Romania.

Considering the reasons provided for in the explanatory memorandum for the amendments to the Pharmacy Law, as well as other documents issued during the legislative process of Law 160 in corroboration with the provisions of Article 85c paragraph 1 and 2 above, it appears that the main reason why the Romanian legislation provides harsher restrictive requirements for the online sale and dispensing of OTC medicines (namely only by the pharmacies/drug stores established under the Pharmacy Law) is for protecting the public health and life of people. Therefore, if such requirements and/or restrictions are justified on grounds of public health protection, such requirements seem to be compliant with the Article 36 of TFEU. Thus, in such cases the Member State should be allowed to impose harsher restrictive conditions.

Of course, as long as no OTC retailer who intends to perform its sale business exclusively online did not challenge such reasons at the European Court of Justice, the Romanian legislation has a strong legality. To this end, until the ECJ will not confirm/infirm such reasons, the above analysed provisions are applicable, and the Romanian authorities are fully competent to sanction any derogations that constitute a breach of law. It is also relevant to be stated that, if such breaches of law do not constitute criminal offence, these may be sanctioned with fines between lei 20,000 and lei 100,000 for repeated breaches, or as the case may be, with annulment of the pharmacy functioning permit (Art. 38 of the Pharmacy Law).

\section{Conclusion}

In a nutshell, as results from the EU legislation and the Romanian legislation quoted above, OTC medicines sold online by either online pharmacies or online drugstores can be delivered to the consumer only from a pharmaceutical unit within the meaning of the Romanian law, namely from a pharmacy/ drugstore authorized to carry out activities related to online sale of medicines, and cannot be delivered directly from a warehouse (located either on the territory of Romania or in another Member State).

Nevertheless, in order to reduce the costs with the delivery of OTC medicines from the warehouse to the pharmacy/drugstore of pharmaceutical economic operators, as well as to avoid blockages on the operational flow, an option could consist in opening a pharmacy/drugstore authorized to carry out activities related to online sale of (OTC) medicines within or near the warehouse, in accordance to the applicable legal provisions.

\section{References}

Pharmacy Law no. 266/2008 published within the Official Gazette I, no 85/ 02.02.20215, republished, further amended.

Treaty on the Functioning of the European Union (Consolidated version dated 26.10.2012), published within Official Journal of European Union, C 326/ 47, https://eurlex.europa.eu/eli/treaty/tfeu_2012/oj. 
Order no. 444/2019 for the approval of the Norms on the Establishment, Organization and Operation of Pharmaceutical Units, published within the Official Gazette, Part I, no. 270/09 April 2019.

https://eur-lex.europa.eu/legal-content/EN/TXT/PDF/?uri=OJ:C:2016:202:FULL\&from=EN. https://eur-lex.europa.eu/legal-content/EN/TXT/PDF/?uri=OJ:C:2016:202:FULL\&from=EN.

Case C-322/01 Deutscher Apothekerverband eV v DocMorris NV and Jacques Waterval, showPdf.jsf (europa.eu).

PICBE |

Directive 2001/83/EC of the European Parliament and of the Council on the Community code relating to medicinal products for human use, published within Official Journal of European Union no. 311/ 28.11.2001, available on https://eur-lex.europa.eu/legalcontent/en/ALL/?uri=CELEX\%3A32001L0083.

Directive (EU) 2015/1535, EUR-Lex - 32015L1535 - EN - EUR-Lex (europa.eu). Directive 1535 repealed Directive 98/34/EC of the European Parliament and of the Council of 22 June 1998 laying down a procedure for the provision of information in the field of technical standards and regulations. 